\title{
Anthony Carlisle and Mary Shelley - Finding Form in a Frankenstein Fog
}

\begin{abstract}
Donald C. Shelton ${ }^{*}$
In 1831 Mary Shelley claimed a dream of fifteen years earlier was inspiration for her 1818 novel, Frankenstein. Despite Mary having made no earlier reference to a dream, the romantic nature of her 1831 claim has prompted its ready and unchallenged acceptance. But can Mary's claim stand up to methodical, detailed, and logical scrutiny? As Albert Einstein stated, "Unthinking respect for authority is the greatest enemy of truth". Here a careful search for the truth, reveals her claim as failing prudent scrutiny. The paper draws on multiple contemporary sources to reveal Mary's 1818 inspiration for Frankenstein was the life and works of Anthony Carlisle, a close friend of William Godwin, and the leading anatomist of his generation. The paper explains that Mary's 1831 claim of a dream was a subterfuge; in simple terms, a lie, invented due to her fear that the truth about her source of inspiration might ignite the prevailing civil unrest; resulting in Britain and its monarchy, together with Sir Timothy Shelley and William Godwin, succumbing to riot and disorder; as had precipitated the 1830 fall of the French monarchy.
\end{abstract}

Keywords: Anthony Carlisle, Mrs Carver, Frankenstein, Mary Shelley, Muscular Motion, Oakendale Abbey

\section{Introduction}

Conventional wisdom holds the inspiration for Mary Shelley's Frankenstein was a visionary dream supplemented by anatomical and chemical knowledge gained from Percy Shelley ${ }^{1}$. But such a view avoids Mary's categoric 1831 denial that she owed anything to Percy for suggesting any incident: "I certainly did not owe the suggestion of one incident, nor scarcely one train of feeling, to my husband". [F:10] Why such an emphatic, almost angry, disavowal? Which, if accepted, leaves her scientific knowledge unexplained? To date, scholars have failed to reconcile her denial to the source of the science within the novel, with many bypassing the conundrum to rely on the dream scenario.

So what was the source of Mary's inspiration and her medical knowledge? The answer to a conundrum is often simple, it just requires a new perspective. Here, that simple answer is a close friend of Mary's father, William Godwin, who was not only the foremost anatomist of his generation, but who had published several Gothic novels; including one focused on an anatomist and his resuscitation of an apparently dead body. That anatomist was Sir Anthony Carlisle, and evidence of his literary efforts was demonstrated in 2009 (Shelton 2009).

\footnotetext{
*Independent Researcher, New Zealand.

${ }^{1}$ The author is grateful to Nora Crook, Stuart Curran, and Charles Robinson for their encouraging him to pursue his research on this subject; he takes full responsibility for his thesis, together with any remaining errors of interpretation or fact. Textual references to Mary Shelley, Frankenstein (London: Penguin, 1992) are as [F] and to Anthony Carlisle, The Horrors of Oakendale Abbey (London: Minerva, 1797; Zittaw Press, 2006), from the Zittaw edition as [O].
} 
Although Carlisle was a friend, and prominent as an anatomist and chemist, hitherto he is largely absent from Frankenstein scholarship.

This paper seeks to sever the "Gordian (Godwinian!) Knot". The process was akin to an archaeological excavation where many surface layers, represented by a plethora of previous opinion, were peeled away, followed by methodical excavation to locate the nineteenth century sources representing Mary's inspiration. Laws of probability identify the prime influences on Mary, the literary sources for her storyline, and the models for her characters. Discussions in the Godwin home included research into Muscular Motion (euphemism for the Secret of Life, to avoid conflict with the Church tenet that only God could create life). The paper reveals how Mary's absorption of that research led her to consider the moral hazard of animation and her choice of Frankenstein as a title. The paper includes a textual analysis of her 1831 revision to show why the revisions became necessary, and then urgent; arising from her fear that the turbulent political and social events of 1826-1831 could spread the French July Revolution of 1830 to Britain.

\section{Mary's Science}

Frankenstein is rightly regarded as a literary classic, but detail of its genesis is foggy. The commonly accepted version is well-known, with Mary realising a vision in a waking dream on 16 June 1816 . An early niggling worry is that only days beforehand, on 25 May and prompted by Byron, Coleridge published his incomplete 1797 masterpiece Kubla Khan. The romanticism of Mary dreaming Frankenstein is appealing, but the link to the composition of Kubla Khan makes this claim slightly suspect.

Evidence tabled here supports Mary's waking dream as a subterfuge. In 1816 Mary and her companions knew of Coleridge's treatment for opium addiction by Anthony Carlisle, and discussion of that may have influenced the gestation of a dream. More likely, in 1831 Mary introduced the dream scenario to avoid questions as to her inspiration, and to deflect attention from Carlisle.

It would require an extensive list to cover all books, papers, and articles expressing opinions about Mary Shelley and Frankenstein, hence the following are tabled as representative. Scholars have exhaustively discussed theories of Mary's science in drawing together her references to anatomy, chemistry, chronology, geography, and literature, as well as canvassing Galvanism and bodysnatching. Those scholars have included Mellor who discussed Francis Bacon, Humphry Davy, Erasmus Darwin, and Luigi Galvani, as well as Adam Walker, Percy Shelley, Laurence Sterne, and Rousseau (Mellor 1988). Followed by Hindle, then Butler and Hetherington who added John Abernethy and William Lawrence (Hindle 1990, Butler 1993, Hetherington 1997). Smith discussed, inter alia, Newton, Lavoisier, Linnaeus, Malthus, Priestley, de Rozier, Harvey, and de Condorcet (Smith 1994). More recently Nicholson was discussed by Curran and 
the science by Ellis (Curran 2001) $)^{2}$. Suggestions as inspiration for Victor by yet more scholars have included; Benjamin Franklin, Cornelius Agrippa, Albertus Magnus, Paracelsus, Aldini, Johann Conrad Dippel, and James Lind.

The theories propounded are chronologically and geographically diverse, with any list of literary sources suggested as inspiration for Mary also extensive. To endorse them requires the assumption of dedicated study, or at least intense assimilation, by Mary in 1815-1817. At a time when she was deeply in love, travelling extensively, frequently changing her residence, three times pregnant, looking after, and grieving for, her babies and for her relatives. She had also to put pen to paper, leaving little time for the wide variety of reading proposed as necessary background for Frankenstein. As just one example, Robert LeCussan writes; "I think it is justified to conclude that Mary Shelley wrote her novel Frankenstein only after reading, re-reading, and consulting the play Prometheus Bound by Aeschylus" (LeCussan 2001: 116).

Academic interpretations of Mary's inspiration and the depth of her message vary widely; from men having babies without women, to Galvansim, and the vitalism debate between Abernethy and Lawrence. Aldini is often mentioned, as is Davy. Those views rely upon Mary absorbing literary, anatomical, and chemical knowledge from Percy, unmet by her before 1814, and despite her categoric 1831 denial.

One way to evaluate Mary's denial is to consider the probability of influence from those favoured by scholars. William Godwin's daily diary includes records of those he visited, as well as visitors to his home. Diary references include: Abernethy 1, Aldini 0, Lawrence 5, Davy 10, Galvani 0, Sterne 0, Erasmus Darwin 2, Lind 0, Byron 6, Polidori 9, Beddoes 2, Radcliffe 0, Baillie 1, Faraday 1, John Hunter 2, Keats 4, Banks 8, Adam Walker 1, Priestley 20, Eldon 1, Malthus 26; a total of 97 mentions for the favourites. Infrequent mentions imply a low probability of influence on Mary; this is why some scholars believe Frankenstein's science was beyond Mary, and needed Percy's hand.

Before accepting that proposition, it is prudent to cast the net wider and consider other influences on Mary. Barry, Carlisle, Coleridge, Holcroft, Nicholson, Hazlitt, Montagu, Thelwall, Opie, Wedgwood, Fuseli, and the Lambs are mentioned 5,352 times by Godwin, over fifty times as many as the 97 of the earlier list. These figures imply the larger group had fifty times the influence. That second group is well researched with one exception, Anthony Carlisle, an anatomist and chemist, who alone has 298 mentions, three times as many as for all the "favourites" combined. Critically, almost all mentions of Carlisle in Godwin's diary were recorded before Mary eloped with Percy.

\footnotetext{
${ }^{2}$ Markman Ellis, Fictions of Science in Mary Shelley's Frankenstein. Retrieved from https://bit.ly/2TbEyvC.
} 


\section{Give Me the Child Until She Is (Twice) Seven...}

The adage, "give me the child until he is seven and I will show you the man", implies a conduit to Mary's knowledge of anatomy and chemistry. The only anatomist fitting that mould is polymath Sir Anthony Carlisle (1768-1840) FRS, PRCS, FSA, FLS, anatomist, biologist, chemist, surgeon, inventor, art lecturer, author, courtier, and social activist. He was surgeon at Westminster Hospital from 1793 to 1840, from c1795 a close friend of Godwin, in attendance at Mary Wollstonecraft's death, in 1808-1824 Royal Academy Professor of Anatomy, in 1817 Professor of Surgery and Anatomy at the Royal College of Surgeons, and also Surgeon Extraordinary to both the Prince Regent and the Duke of Gloucester (Carlisle 1817).

Figure 1. Carlisle, by Henry Bone after Shee - author

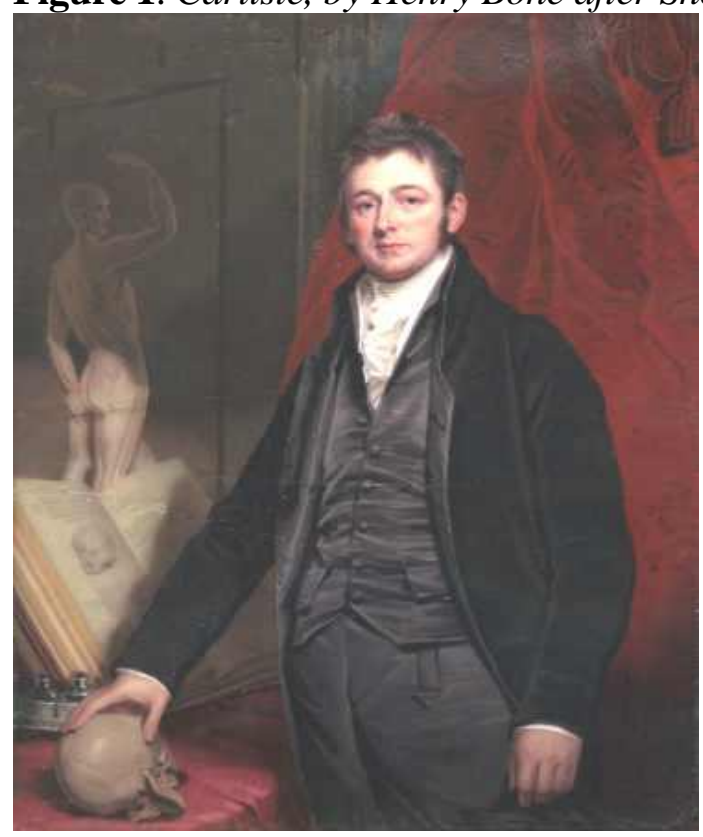

Carlisle's portrait (Figure 1) shows his clothing as friend and author, but Bewick noted Carlisle as an eccentric lecturer, "in full court dress, with bagwig, curled and powdered, his cocked hat, and lace ruffles to his wrists" (Bewick 1871: 140). The anatomist in Hugh Trevor is Carlisle as Holcroft saw him, "a man with an apron tied round him, having a kind of bib up to his chin, and linen sleeves drawn over his coat" (Holcroft 1973: 289-297).

In early 1800 Carlisle became famous as a chemist after his discovery of electrolysis; "Mr Carlisle has lately made some interesting experiments which prove the identity of the electric and galvanic fluid. ...an uninterrupted stream of the electric fluid, which being passed through water, decomposes it completely" (Tilloch 1800: 372). The experiments were repeated with Nicholson. As a result Carlisle was appointed to the influential Royal Institution Chemistry Committee and elected to the Royal Society. He presented many scientific lectures to the Linnaean Society, the Royal College of Surgeons, the Royal Society, and the 
Royal Academy, where he gave an annual series of public lectures on anatomy between 1808-1824. On various occasions the lectures featured Chinese jugglers, soldiers performing sword exercises, invisible writing, and Gregson the pugilist. The crowds attending resembled those at modern "rock-star" concerts; "There were times when the anatomy lectures at the RA drew such crowds that people fought to get in, and officers from Bow Street had to be stationed at the door to keep out the disorderly element. Those were the addresses of Carlisle, when he was Professor of Anatomy at the RA" (Bewick 1871: 142).

Carlisle was related by marriage to Byron, as the step-mother of his wife, Martha Symmons, was Ann Trevanion, widow of Byron's great-uncle William Trevanion. Ann married John Symmons at Bath on 24 March 1773, shortly after Martha's mother, died in childbirth. Martha's father, John Symmons FRS, FLS, a noted botanist and bibliophile with a library of 40,000 volumes, was a founder of the Literary Fund, a manager of the Royal Institution, a Dilettanti, and a member of the Nobleman's and Gentleman's Catch Club, of which the royal Dukes were also members. Martha's uncles were Manasseh Dawes, author and barrister who defended both Rev William Dodd and Rev James Hackman, and Charles Symmons, author of a Life of Milton and later a Life of Shakespeare. Martha's cousins included Aeschylus translator, John Symmons AM and Milton devotee, Caroline Symmons, whose 1812 Poems, especially Zelida and the Faded Rose-bush Which Grew Near Her Tomb, represented appropriate reading for Mary at her mother's grave (Symmons 1824, Wrangham 1804: 25, Symmons and Symmons 1812: 37).

The friends, colleagues, and patients of Carlisle included Holcroft, Opie, Nollekens, and Turner, also the actor Edmund Kean and scientists Banks, Davy, and Gurney. Carlisle curated the RCS Museum and undertook notable autopsies including those of John Opie in 1807, Thomas Holcroft in 1809, and Chevalier d'Eon in 1810. He was feted at society dinners for his anatomical experiments, with his servant answering a query from Lady Cork; "Oh! This is not the place where we bottle the children, that's at master's workshop" (Fitzpatrick 1860: 259).

In 1814 John Davy paid tribute to Carlisle's anatomical knowledge; "the observations that have been collected are very few in number and with the exception of those of Messrs Hunter and Carlisle are scarcely perhaps deserving of confidence" (J. Davy 1814: 590). Abernethy also acknowledged the importance of; "Mr Carlisle in whose talents and accuracy we are all disposed to place confidence" (Abernethy 1814: 26). In 1816 Mary read Elements of Chemical Philosophy, where Carlisle's research with an air pump and Volta's battery is discussed by Humphry Davy who, in his 1826 Bakerian Lecture, described Carlisle's discovery of electrolysis as the true origin of electrochemical science $(\mathrm{H}$. Davy 1812: 54). In 1825 Carlisle's knowledge of the human body was bracketed by Alexander Monro with the greatest; "the proportions of its several component parts from Leonardo da Vinci, Soemmering, and Sir Anthony Carlyle [sic]" (Monro 1825: xxviii).

Mary Wollstonecraft had intended that Carlisle revise her proposed new book and in 1823 he was described by Charles Lamb as "the best story teller I ever heard" (Lamb 1905: 602), with Robert William Elliston reminiscing; "O! it was a 
rich scene - but Sir Antony [sic] Carlisle, the best of story tellers and surgeons, who mends a lame narrative almost as well as he sets a fracture, alone could do justice to it" (Robert Elliston, quoted in The Annual Biography 1832: 6). William Clarke recorded; "We have found [Carlisle] even more agreeable as a private talker than as a lecturer; he is rich in the old lore of England, - he will hunt a phrase through several reigns, - propose derivations for words which are equally ingenious and learned, - follow a proverb for generations back, and discuss on the origin of language as though he had never studied aught beside" (Clarke 1827: 170). Carlisle authored novels under the pseudonym, Mrs Carver, which were likely available at Godwin's bookshop.

As family friend and respected anatomist, but with a showman-like reputation, Gothic novelist Carlisle was better placed than any other to inspire Mary to author a novel featuring an anatomist.

\section{"In the Gloomy Month of November"}

Mary's pre-1815 reading list is lost and her Journals of May 1815 to July 1816 are missing. In addition Charles Robinson records; "the 'transcript of ...[her] waking dream' ...does not survive. Nor do we have any of the discarded 'foul papers' or early drafts of the novel that she continued to write during July and August 1816" (Shelley 2008: 16). These gaps in an otherwise comprehensive archive, invite a question as to whether Mary deliberately purged her files in 1831, as they contradicted her dream scenario?

Another logical question is whether books on Mary's pre-1815 reading list had influenced her? That is addressable by identifying elements of plot or style which re-emerge within her novel. A recent paper in Romantic Textualities demonstrated The Horrors of Oakendale Abbey and The Old Woman, Gothic novels previously attributed to Mrs Carver, were actually written by Carlisle (Shelton 2009). Analysis of two further Mrs Carver novels, Elizabeth, and The Legacy reveals more Carlisle "fingerprints". For example in paralleling his selection of the city of Carlisle as a setting in Oakendale, a key setting in Elizabeth is the city of Lisle (now Lille) in France, as a word-play on Car-Lisle (Carlisle 1797: 129).

Carlisle authored various academic papers and in 1797 published two novels, Oakendale and Elizabeth (3 vol). The Bodleian Library contains a Carlisle letter (Figure 2) to Godwin of 14 October 1797 referring to this; "my own pamphlets and new Books are distributed all over the Country"3

\footnotetext{
${ }^{3}$ Anthony Carlisle. Retrieved from https://bit.ly/2BQH2Wp.
} 
Figure 2. Carlisle's 1797 "new Books" letter, Bodleian Library

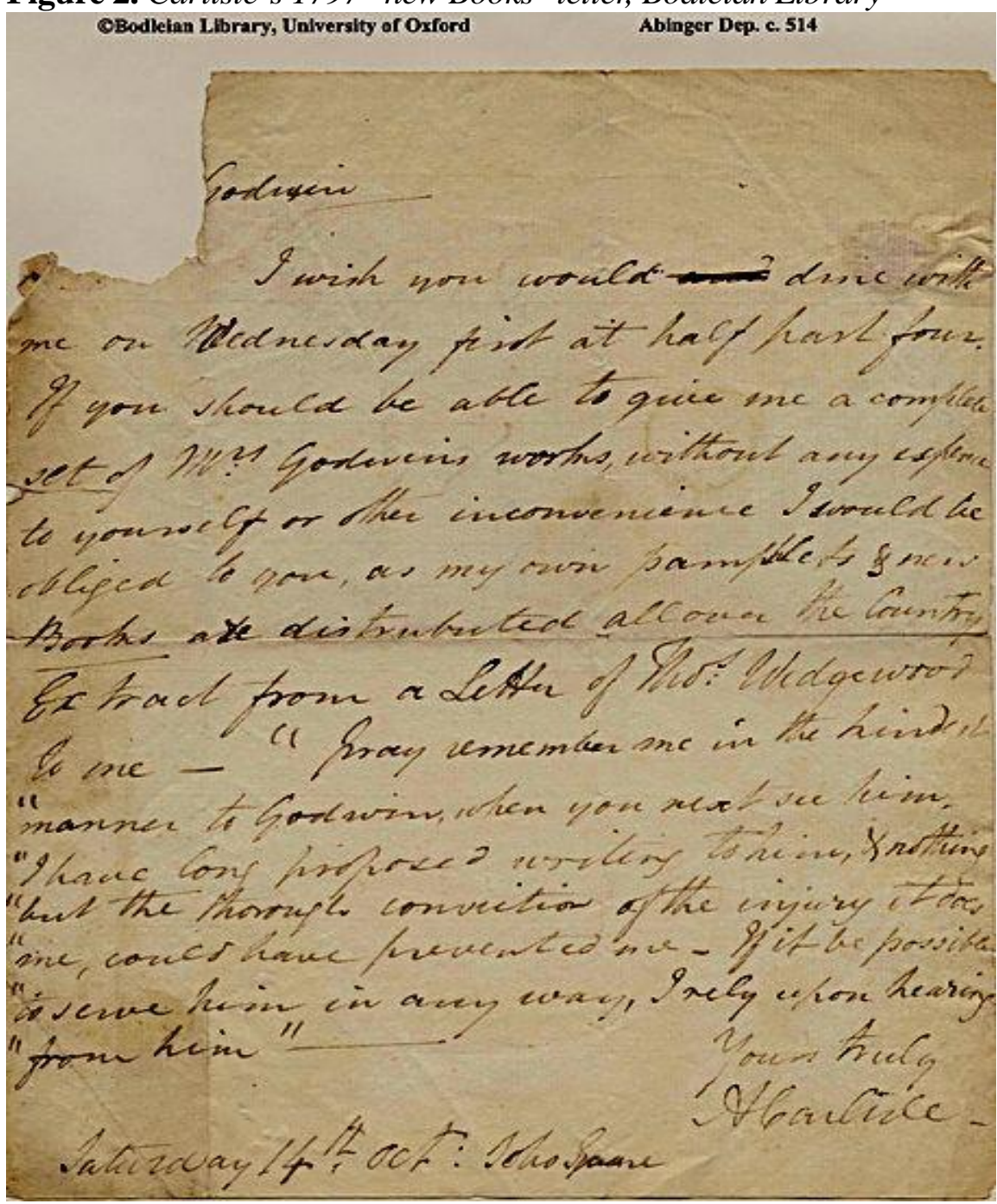

The reanimation of an executed felon in Oakendale was Mary's inspiration for Frankenstein, but attempts at reanimation are traceable back to the eighteenth century. They include a failed attempt by John Hunter, on 27 June 1777, to revive Rev. William Dodd after his removal from the Tyburn gallows. As a favourite student of Hunter, Carlisle was familiar with his theories and in Oakendale a like attempt to revive a felon is successful, but the consequences are not discussed. The consequences of such a revival without a memory became the subject of Mary's Frankenstein, and in her Roger Dodsworth she considered the consequences of revival with a restored memory.

Mary records herself as imitating the style of others, "As a child I scribbled; and my favourite pastime...was to 'write stories'. My dreams were at once more fantastic and agreeable than my writings. In the latter I was a close imitator rather doing as others had done than putting down the suggestions of my own mind". [F:5] As "close imitator" Mary drew key incidents from two books, Oakendale by Carlisle and The Adventures of Hugh Trevor, by his close friend Thomas Holcroft, the latter recorded as read by her in 1816. Anatomists who 
body-snatch are central to both novels, as with "those wretches, and pests of society, called Resurrection men, who brought numbers of bodies to Oakendale Abbey". [O:179] Her initial tale was too short and she was encouraged to expand it, resulting in a "Russian dolls" structure of letters, narrative, and monologue. Following Carlisle's lead Mary elected to wrap the epistolary style of his Old Woman around his Oakendale narrative, itself enveloping a 24 page monologue of Laura Carleton's history (Carl-isle begat Carle-to(w)n).

Oakendale opens with the words "In the gloomy month of November...". [O:25] Mary echoes this with, "It was on a dreary night of November...". [F:56] Mary also borrows a key element from Oakendale, where a tall, mute, "creature" reanimates from the apparently dead and escapes the anatomist. That "creature" was a hanged felon revived after a hangman's noose at Carlisle had failed its task. [O:180]

Laura gave a fearful shriek, when a tall figure, dressed only in a checked shirt, staggered towards her. The face was almost black; the eyes seemed starting from the head; the mouth was widely extended, and made a kind of hollow guttural sound in attempting to articulate. [O:73]

For Mary, as a young reader of Oakendale identifying with Laura, that fearful encounter was deeply imprinted on her mind; to be recalled when she wrote Frankenstein. Mary used images and words clearly linked to this passage in presenting her Creature; "his eyes, if eyes they may be called, were fixed on me. His jaws opened, and he muttered some inarticulate sounds". [F:57]

Although written twenty years apart, Oakendale and Frankenstein include almost identical long monologues. Laura's monologue in Oakendale reveals her mother, Zelima as a Greek lady originally captured by Algerian Corsairs. Laura is captured and cast by the French into a Paris prison. Laura is rescued from the prison by $\mathrm{M}$ du Frene who looks after her. While in Paris Laura meets and falls in love with Eugene, but his guardian recalls him to England. "Eugene at first declared he would not obey the mandate, and that he had long enough submitted to the control and caprice of those whom he really believed had no right to direct, or take any part in his conduct". [0:95] Nevertheless Eugene leaves for England. When du Frene is executed during the French Revolution, Laura flees from Paris to England with her attendant to be reunited with her lover, Eugene. [O:83-106, 144]

The Creature's parallel monologue in Frankenstein reveals Safie's mother as a Christian Arab originally captured by Turks. Safie's father is captured and cast by the French into a Paris prison. He is rescued from the prison by Felix De Lacey, who escorts the Turk and Safie from Paris to Leghorn. While in Paris Safie meets and falls in love with Felix, but her father commands her to think no more of him. "The generous nature of Safie was outraged by this command; she attempted to expostulate with her father, but he left her angrily, reiterating his tyrannical mandate". [F:122] When her father tells Safie she must then leave for Constantinople, Safie flees from Leghorn to Germany with her attendant to be reunited with her lover, Felix. [F:99-139]

In fleeing France, Laura lands at Milford Haven, Wales in late 1792; close to 
Slebech where Carlisle's father-in-law, John Symmons, resided. [O:97] Arriving at the Abbey, Laura finds evidence of body-snatching, without meeting the anatomist. In 1792 Carlisle was aged 24 and modelled his unnamed anatomist on himself. Descriptions in Oakendale and Hugh Trevor prompt Victor's experiments in Frankenstein, all three novels drawing on Carlisle's own research.

[Laura] was struck with horror and astonishment when the skeleton of a human body presented itself to her afrighted view! ...her eye endeavoured to scrutinize and investigate every object it could through a space so narrow; when, after a slight noise, and a shade of something darkening the view, a large rolling eye-ball met her own, and she instantly sunk down... The dead body of a woman hung against the wall opposite to the door she had entered, with a coarse cloth pinned over all but the face; the ghastly and putrefied appearance of which bespoke her to have been sometime dead... There were evident marks of blood upon many parts of the floor, and in one corner lay a human skull! [Oakendale: 47, 63, 73, 152]

[W]e found ourselves assaulted with a smell, or rather stench, so intolerable as almost to drive us back, and left us, not only with the dead hand, not only with the dead body, but in the most dismal human slaughterhouse that murder and horror ever constructed, or ever conceived. ...by the light of the lanthorn, we beheld limbs, and bones, and human skeletons, on every side of us. I repeat: horror had nothing to add. ...Here preparations of arms, pendent in rows, with the vessels injected. There legs, feet, and other limbs. In this place the intestines: in that membranes, cartilages, muscles, with the bones and all their varieties of clothing, in every imaginary mangled form. [Hugh Trevor] (Holcroft 1973: 293)

In Oakendale Carlisle leaves detail of the re-animation off-stage, and instead casts himself as Eugene. Mary deserves credit for developing the risks associated with revival of the felon, perhaps asking, "Mr Carlisle, what happened to the fleeing felon? - and did the anatomist also flee?" In Frankenstein Mary speculates on the fate of the anatomist, and of the fleeing felon.

Aspects of Oakendale and Frankenstein meld inversely as positive and negative images. Laura is the gentle antithesis of Mary's Creature, as is Eugene the antithesis of Victor. In Oakendale, Carlisle as Eugene regains Laura, a title, and riches, but in Frankenstein Carlisle, as Victor, loses the Creature, his happiness, and his life.

\section{Character Inspiration}

Events in Frankenstein echo the life and works of Carlisle. Popular culture has accepted the appellation Dr Frankenstein. However, apart from physician, Dr Erasmus Darwin, Mary makes no use of the word doctor; being conscious from Carlisle the term applied only to those practising as a physician. As a surgeonanatomist, Carlisle merited the courtesy title Mr; hence references to Victor the anatomist should properly be Mr Frankenstein.

For his novels "Mr Carlisle" adopted the pen-name "Mrs Carver", a pun on his occupation of a surgeon "carving meat". Carlisle had a predilection for similar word-plays. Apart from those in Oakendale, his Old Woman includes $\mathrm{Mr}$ 
Goodworth, a clergyman, for Godwin, who had trained as a clergyman. Also letters written to Mrs Elinor Safforey, drawing on letters written to Mrs Edith Southey by Robert Southey during visits to Carlisle's home; one letter even complaining about the poor quality of Carlisle's writing materials.

Ingolstadt in Frankenstein can be accepted literally, but Oakendale offers a model for a different interpretation. Oakendale is based on actual people and events in London and Wales. To protect their identities, Carlisle "transports" events to the northern English city of Carlisle and places Oakendale abbey in the adjacent region of Annandale, with Oak-endale as a play on Ann-andale.

To protect identities, Mary follows Carlisle's Oakendale example, in transporting London events to the Continent and blurring relationships. So why choose a university in Ingolstadt? Scholars have advanced esoteric theories rationalising her choice, but the simplest explanation is the linguistic bridge to the colloquialism, "London Town". "Anglia" is Latin for England and German "stadt" means town, with Ingolstadt then a word-play on Ingol-town as Anglo-town, i.e. London Town.

Mary imitates the epistolary style of Old Woman with letters to Mrs Saville [cf. Mrs Safforey and Mrs Southey]. Also the drowning of Clerval, whose body is recovered by fishermen between Ireland and Wales, the same area as a body recovered in Old Woman. Elizabeth Lavenza's name, description, and character draw on Elizabeth Spencer in Carlisle's Elizabeth. In Frankenstein professor M Krempe is a play on Peter Camper, the famous Dutch anatomist. Early in Frankenstein, Walton states, "Twice I actually hired myself as an under-mate in a Greenland whaler". [F:15] Carlisle's predecessor as RA Professor of Anatomy, John Sheldon, did sail on a Greenland whaler to experiment with a poisoned harpoon to kill whales (Thornton 1809: 197).

Some scholars have identified doppelgängers in Frankenstein; a view paralleling Carlisle's symptoms of Asperger's Syndrome and resultant complex personality. Other historical figures afflicted with Asperger's include Leonardo da Vinci, Isaac Newton, Benjamin Franklin, Charles Darwin, and Albert Einstein. Mary sensed the differing personalities in Carlisle; with her perception of his inner conflicts, together with the spectre of his female alter ego, Mrs Carver, assisting in developing her characters.

- Firstly, Carlisle, her father's friend who tried to save her mother at the time of Mary's birth. He is represented by Henry Clerval.

- Secondly, Carlisle, Professor of Anatomy. Waldman's words echo views expressed by Carlisle, with Waldman's description matching a Henry Bone portrait of Carlisle, who turned fifty in 1818; He appeared about fifty years of age, but with an aspect expressive of the greatest benevolence, a few grey hairs covered his temples, but those at the back of his head were nearly black. His person was short, but remarkably erect... [F:46]

- Thirdly, an experimental anatomist of c1792 seeking the secret of muscular motion. This 25 year younger Carlisle becomes Victor, but with Mary playing the character in the first person as her own male alter ego, interspersed with blurred references to her family and life experiences. 
In Frankenstein, Waldman refers to modern philosophers where the attributes describe Carlisle. [F:47] As an anatomist he researched "the recesses of nature", from tapeworms to humans. As natural philosopher he had made a model hot air balloon to "ascend into the heavens", he presented papers describing "how the blood circulates" and his splitting of water into oxygen and hydrogen, shows his understanding of "the nature of the air that we breathe". The "thunders of heaven" refers to the electricity of lightning, and "earthquakes" to how mild electric current made people jump and their muscles move, a key element of Carlisle's research. The last, to "mock the invisible world with its own shadows" is less obvious, but refers to the chemistry in Carlisle's c1800 silver-nitrate photographic experiments with Thomas Wedgwood, wherein they were unable to fix their photographic images, which faded into shadows and thence invisibility (Carlisle 1839: 329).

\section{Muscular Motion and Reanimation}

Many famous anatomists have delivered Croonian lectures on Muscular Motion. Carlisle's Croonian lectures of 1804, 1805, and 1807 reveal he was seeking to reanimate life by using electricity to reverse the coagulation of blood. Carlisle had been a favourite student of John Hunter and followed his lead in theorising blood contained the life force to power muscles; so answering Victor's question; "Whence, I often asked myself, did the principle of life proceed?" [F:50] Carlisle coined the term hibernate, but John Hunter earlier considered reanimation from a frozen state; "I fancied that if a man would give up the last ten years of his life to this alternate oblivion and action, I might prolong it for a thousand years, by thawing him every hundredth anniversary, when he might learn what had happened during his frozen condition" (Adams 1818: 88).

Hunter's theme re-emerges in Roger Dodsworth, the Reanimated Englishman, Mary's 1826 tale of a man unfrozen after 200 years. Mary revises "a thousand years" to "some ten centuries", with plays on Mount St Gothard, as "got frozen", Mr Dodsworth, for Rev William Dodd, hanged after an unsuccessful defence by Martha Carlisle's uncle; and Dr Hotham, "hot ham" [i.e. thawed], for Dr Hunter, whose 1777 attempt to reanimate Dodd had failed.

Carlisle commissioned his portrait in 1824, midway between the two Frankenstein editions. The iconography invites the title, The Discovery of Muscular Motion, to celebrate Carlisle's anticipated ability to raise a body from premature death. As RA Professor of Anatomy for the previous 16 years, no man was better placed to devise the iconographic "anatomy" of his portrait. There are two inkwells, an iconographic hint that he wrote as Anthony Carlisle and Mrs Carver. His research objective is seen through a door to the future. A model with muscles more clearly delineated than was normal for art models of the time, implies a man rising from the recently dead, with a shroud in his left hand, and a raised right arm beckoning the viewer (Figure 3). 
Figure 3. Detail - Human Reanimation

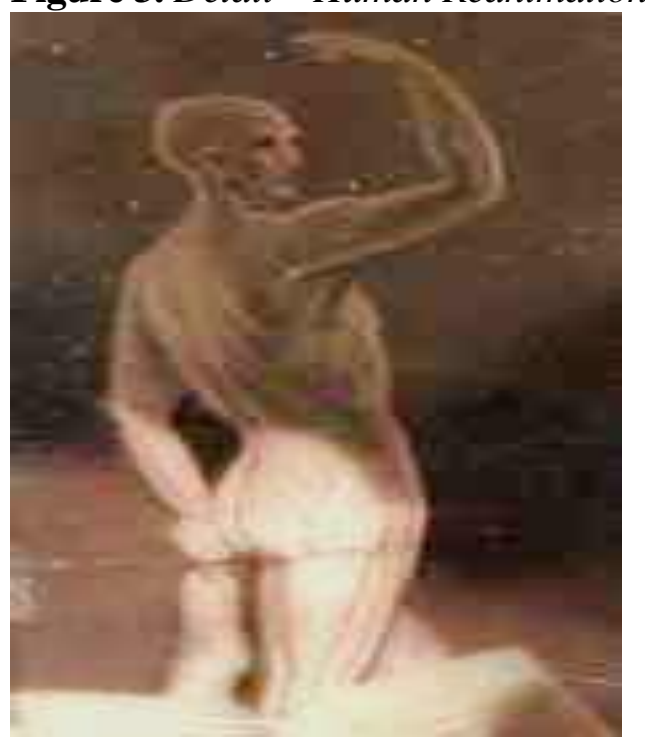

In a pun on "the human fabric", the knowledge of Carlisle, as his hand on the skull, converts dry blood coloured fabric on the left, or evil side, to the upright, healthy, right-hand fabric, the colour of fresh blood. The light on the 1543 anatomical text by Vesalius, De humani corporis fabrica, the leg muscles, and shroud, implies Carlisle's belief his anticipated revival of the recently dead would ensure his lasting fame. An aim paralleling Clerval, whose "dream was to become one among those whose names are recorded in story, as the gallant and adventurous benefactors of our species". [F:37]

Mary replicated Carlisle's 1824 iconography in her 1831 frontispiece (Figure 4) and, contrary to modern interpretations, elected to depict a tall, naked, wellbuilt, male cadaver, rising from the dead, with a shroud and one raised arm, together with an anatomist, a human skull, an open book, and a open door. Plus a pump (Figure 5) connected to a Volta battery (Figure 6), for machines Mary saw at Carlisle's home.

Figure 4. 1831 Frontispiece

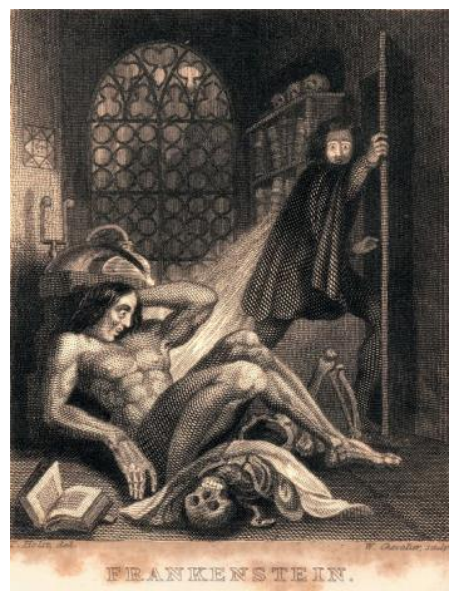

Figure 5. Detail of Machine

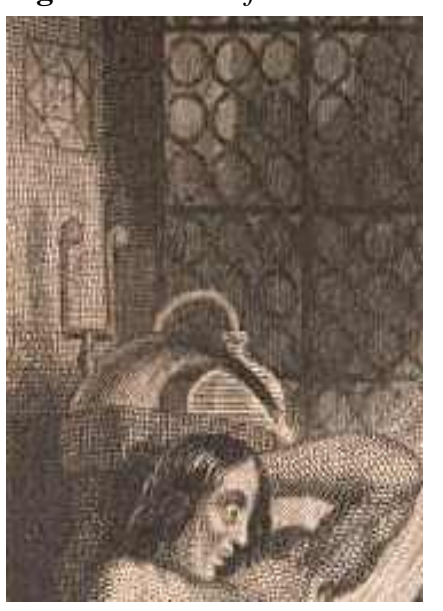

Figure 6. Early Volta Battery

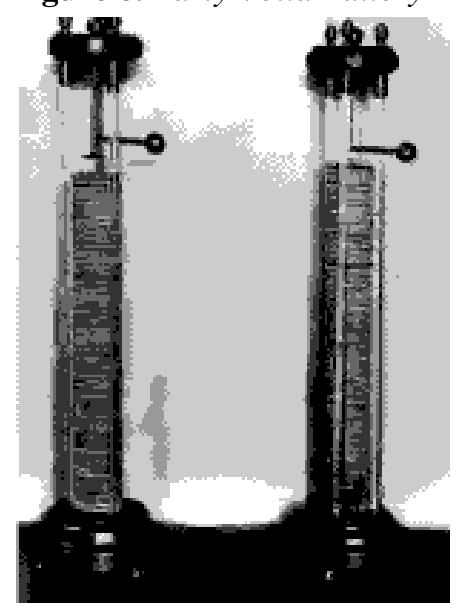


An aspect unclear in Frankenstein is the source of the Creature but there is logical reason. Mary must have heard alarming reports of body-snatching near her mother's St Pancras grave, as multiple instances occurred, with at least 46 bodies snatched there in 1812 alone (Bailey 1896: 154-160, 176). In 1816 a gang of disgruntled body-snatchers broke into St Thomas's dissecting room, terrorised the students, and hacked the corpses into useless fragments. For Mary to promote Victor as reviving a body-snatched subject was untenable.

\section{Sarah Stone's Mummy and Mary's Creature}

Carlisle's RA lectures included displays of body parts, as when William Hazlitt had a struggle to keep from fainting when Carlisle passed round platters containing a human head and a human heart; while discoursing on art inspired from the head and from the heart (The Burlington Magazine 1913: 257). Discussion of this at Godwin's home led to Mary's initial inclination for the assembly of body parts into a human, but she revised this after discussion with Carlisle; "On this occasion a man of great research in natural philosophy was with us...he entered on the explanation of a theory which he had formed on the subject of electricity and galvanism, which was at once new and astonishing to me". [F:40]

Mary's reaction alludes to Carlisle's well-attended anatomy lecture of 13 November, 1815 where he announced the arrival 11 weeks earlier, of a second modern mummy for public display (The New Monthly Magazine 1815: 439). The earlier mummy had arrived at the RCS in 1808 and led to speculation among Carlisle's friends about reanimating a modern mummy as a means of reviving life. This concept, together with reviving a body from freezing, drowning, or asphyxiation, was seen as publicly acceptable. Mummification was discussed by Matthew Baillie in 1804 and republished in 1812; "According to Dr Hunter's method, embalming is begun as soon after death as decency will permit. ...the operation should take place after a very short interval, viz. of not more than two or three hours after death" (Baillie 1812: 13).

The two modern mummies were prepared by Carlisle's predecessors as RA Professors of Anatomy, William Hunter and John Sheldon, the latter embalming and keeping the mummy of his mistress in his home for thirty years. Although often described as Miss Johnson (a gender word-play on "Miss John's son"), Sheldon never lied to his friends about the mummy; said to be Sarah Stone, a medical artist who worked for Sheldon and William Hunter's assistant, Cruikshank (Litten 1991: 50). Sarah Stone's mummy arrived at RCS in 1808 (Figure 7) and was earlier described as;

$[\mathrm{U}]$ nder a glass frame I saw the body of a young woman, of nineteen or twenty, entirely naked. She had fine brown hair, and lay extended as on a bed. The glass was lifted up, and Sheldon made me admire the flexibility of the arms, a kind of elasticity in the bosom, and even in the cheeks and the perfect preservation of the other parts of the body. ...to imitate the natural tint of the skin of the face, a coloured injection was introduced through the carotid artery (Faujas de St Fond 1799: 43). 
Figure 7. Sarah Stone resembled this Life-sized Wax Effigy in the Specola Collection (http://individual.utoronto.ca/twix/anatomy/images/bellareclined.jpg)

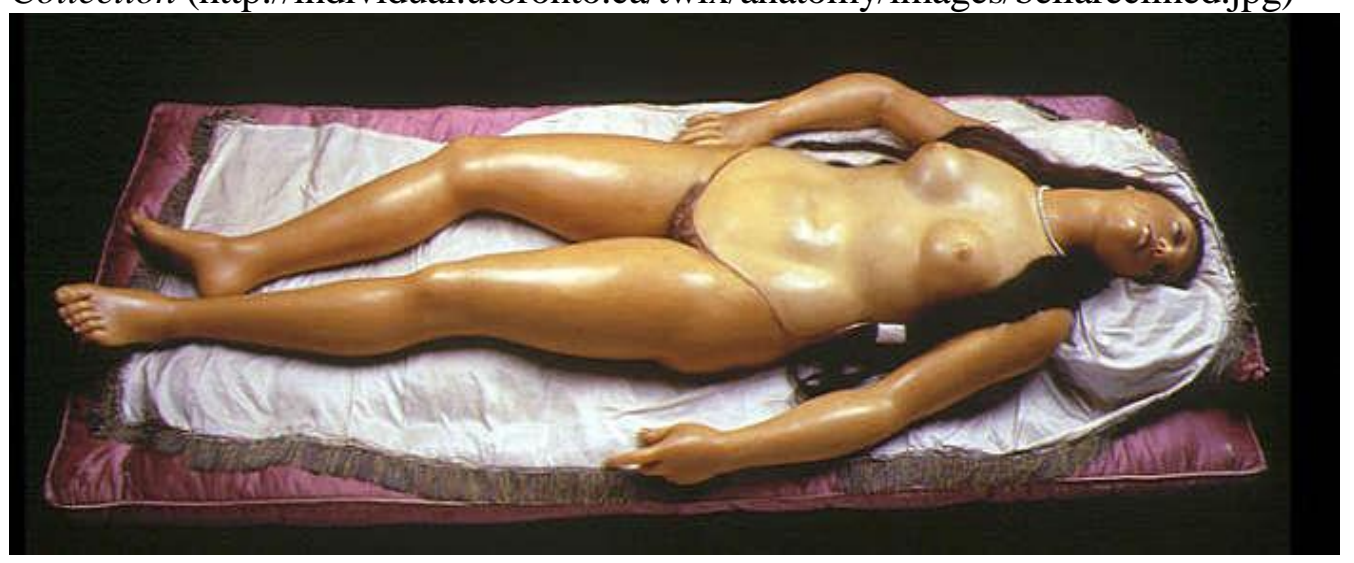

Sheldon and Hunter also embalmed, after her 14 January 1775 death, Maria, wife of Martin van Butchell; who then exhibited her mummy in his home. Maria's mummy was described; "The face is completely preserved; and it is justly considered a curious specimen of what art can accomplish" (Leigh 1824: 339). Her mummy arrived at the RCS Museum on 24 August 1815 and, as RCS Curator, Carlisle arranged display of both mummies.

Previous writers reject Mary's Creature as a mummy, as Egyptian mummies were dark brown in colour. But Mary contemplated revival of a mummy; "A mummy again endued with animation could not be as hideous as that wretch" and she later describes its hand as "like that of a mummy". [F:57, 211] With a female/male gender switch, Mary's references to yellow skin and dun-white sockets reveal she had viewed Maria van Butchell and Sarah Stone as modern mummies, one more attractive than the other.

[Her] yellow skin scarcely covered the work of muscles and arteries beneath; [her] hair was of a lustrous black, and flowing; [her] teeth of a pearly whiteness; but these luxuriances only formed a more horrid contrast with [her] watery eyes that seemed almost of the same colour as the dun-white sockets in which they were set, [her] shrivelled complexion and straight black lips. [F:56]

A woman was sleeping on some straw; she was young, not indeed so beautiful as her whose portrait I held; but of an agreeable aspect and blooming in the loveliness of youth and health... And then I bent over her, and whispered, "Awake, fairest, thy lover is near"... The sleeper stirred... [F:139]

Mary's plot shies away from her Creature kissing Sarah Stone's mummy in the manner of Sleeping Beauty; instead he demands, "My companion must be of the same species, and have the same defects. This being you must create". [F:139]

In assessing Carlisle/Mrs Carver and Frankenstein hints of literary gender switching were set amid a real life parallel. In 1810 Carlisle autopsied Chevalier d'Eon, after years of debate about d'Eon's gender; even a 1778 landmark court case, Da Costa $v$ Jones, wagering d'Eon was female. The autopsy revealed as a 
man, what many believed a woman; in effect Carlisle converted a woman into a man (Taylor 1858: 660).

At the RCS museum Mary also saw the skeleton, still on display, of eight foot, Irish Giant, Charles Byrne whose skeleton Carlisle had worked on with John Hunter. It took little for Mary to convert one mummy into a male who, on reanimation, lacks a memory. She was inspired by the giant in Oakendale; "God preserve us! Here is a dead man, bigger than a giant. With saucer eyes, and huge limbs!". [O:112]

As depicted in her frontispiece, he was an amalgam of Charles Byrne, coupled with the bodily perfection of pugilist Bob Gregson. Farington recorded attending a breakfast given by Carlisle at his Soho Square home in 1808, where Gregson was displayed in the drawing room striking poses, while Carlisle's friends wandered around for half an hour admiring his muscle groups.

A fair question is why did Mary choose Frankenstein as a title ahead of any other place name, and why apply it to a person, instead of a location? In learning of Castle Frankenstein she realised a basic translation of Frankenstein was ideal for her hero. One mummy curated by Carlisle was Sarah Stone, and Frankenstein translates as Franc/Frank (Fr-free/G-open), en/an (Fr-out of/G-up), stein (G-stone), i.e. "free out of stone". A play on Carlisle/Mrs Carver as a "carver of stone" reanimating Sarah Stone; the reverse of the mummification applied to Maria van Butchell, "turned to stone" by Hunter and Sheldon.

To do his wife's dead Corps peculiar honour,

Van Butchell wish'd to have it turned to stone,

Hunter just cast his Gorgon looks upon her,

And in a twinkling see the thing is done

(Richard Jebb, quoted in Stephenson Payne 2007: 112).

In anatomical terms "to prepare a frame" describes arriving at a specimen for display, including injecting coloured wax into the blood vessels. Or, in Frankenstein using Carlisle's proposed electrical machine to revive blood, and pump it into the blood vessels, muscles, and fibres of an executed felon or mummy; "I saw the hideous phantasm of a man stretched out, and then, on the working of some powerful engine, show signs if life, and stir with an uneasy, halfvital motion". [F.9]

Although in good condition in 1815, by 1899 one mummy no longer had "any semblance of life but was shrunken and hard as a board, the skin of the arms, neck and chest quite white but the face, where apparently the colour injected remained, a dull red, all the more ghastly for its colour, and the long brown hair is beautiful no more" (Anon 1899: 1342). The mummies were destroyed by bombs in World War II.

\section{Reanimation as a Moral Hazard}

In 1804 James Barry completed his famous work Birth of Pandora (Figure 8) and around that time fell ill. Barry had just strength enough left to crawl to his own 
front door, open it, and lay himself down with a paper in his hand, on which he had written his wish to be carried to the house of his close friend Carlisle. Barry died in 1806 and his painting links Carlisle's search for muscular motion to Mary's recording of the risks, seen by her as equivalent to opening Pandora's Box.

Figure 8. Birth of Pandora, James Barry, ( Manchester City Galleries

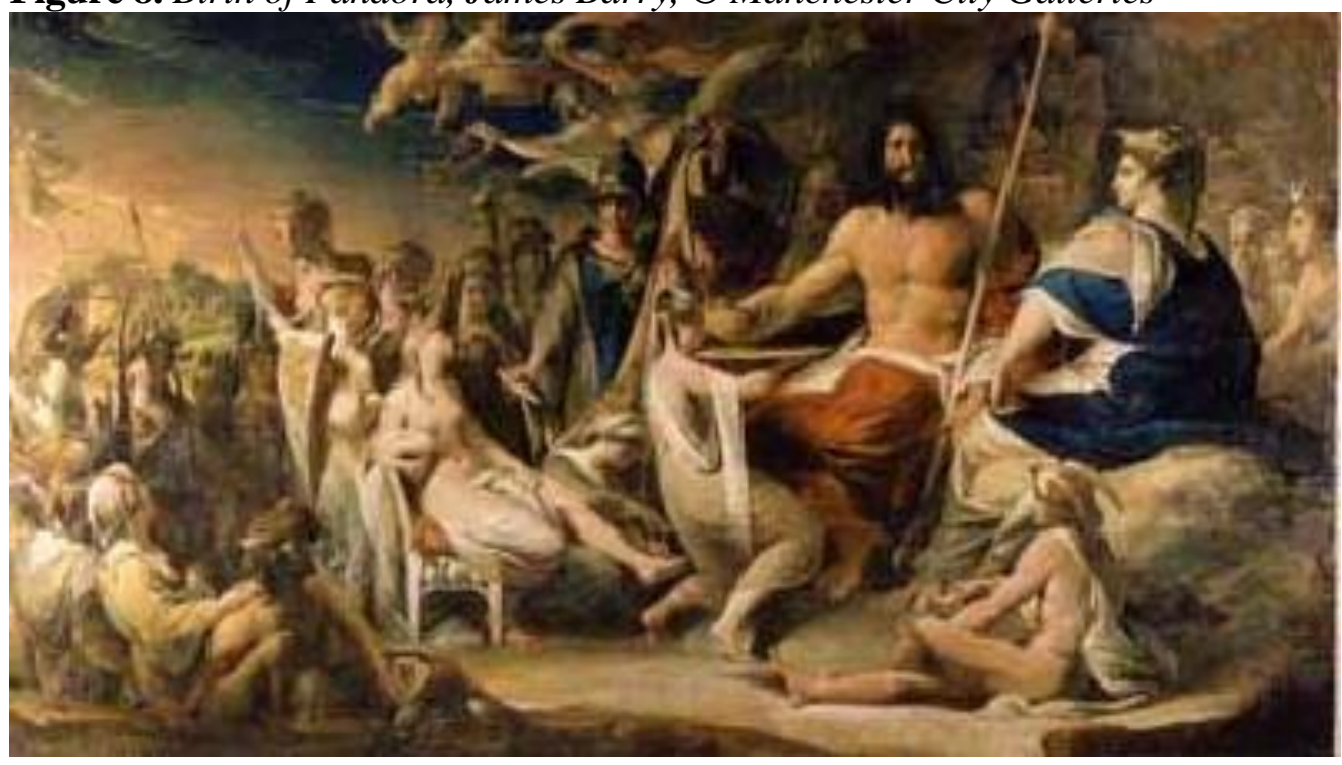

Carlisle was concerned about the practice and ethics of Galvanism and, in 1815, "deprecated the cruel experiments of some late and present anatomists; conjured the students never to lend themselves to such tortures for the discovery of the hidden principles of vitality, which he declared to be worse than useless, as this principle was one of those wisely concealed from our present view" (The New Monthly Magazine 1815: 439). Significantly Carlisle referred to "concealed from our present view", and repeated his warning in 1816, "he even ventured to reprobate in strong terms the horrid tortures which some modern physiologists practise and a distinguished society make public" (The New Monthly Magazine 1816: 59). But in an era when the word "disease" had the wider meaning of "disease", Carlisle hinted at his own research into a theory of life;

Desperate operators should be reminded, that it is not uncommon for persons to recover from diseases, which are generally supposed to be mortal; but I must reserve the further observations upon that grave and momentous subject, until I am enabled to lay before the Public the particular evidences of my own practice, and my special deliberations upon Surgical Ethics (Carlisle 1817: 109).

Mary has Victor echo Carlisle, "what glory would attend the discovery, if I could banish disease from the human frame and render man invulnerable to any but a violent death!". [F:39] Carlisle believed he was close to reviving life in his letter of 5 August 1823, as written to Samuel Parr. The timing is significant, around the time Carlisle was sitting for his oil portrait and hopeful of success. 
I feel an interested vanity in wishing you to see the ultimate work of my cogitations. A work so wide in its moral and physical bearings that I dare not say what it is, excepting that the same has been contemplated by many of the first Philosophers, of all ages and countries, and that it embraces a great number of natural facts which conspire to effect a most important practical result (Antony Carlisle, quoted in Johnstone 1828: 188).

The terms "my special deliberations upon Surgical Ethics" and "wide in its moral and physical bearings", show Carlisle pondering the implications of revival; touching on views discussed in Godwin's Essay on Sepulchres and Montagu's The Opinions of different Authors upon the Punishment of Death, both published in 1809 .

If an executed felon or mummy was revived, and its mind was blank, could it be claimed as a new species? Or if a felon was revived along with its memory, would it have the same personality as before death? If so, had it been punished enough for its crime? Should a felon be executed again? If so, how many times? Would execution become an ineffectual punishment? Who, and how should a revived mind be taught? How would it learn? Then who would be responsible for any subsequent crimes, the revived human or its teacher?

These themes appear in Frankenstein, as where the Creature notes, "all my past life was a blot, a blind vacancy in which I distinguished nothing". [F:117] They were widely canvassed; Fessenden's epic, satirical, poem of 1803, Terrible Tractoration, scorned Aldini's attempt to revive the executed Forster;

\section{And as he can (no doubt of that) \\ Give rogues the nine lives of a cat; Why then, to expiate their crimes, \\ These rogues must all be hung nine times \\ (Green Fessenden 1803: 65).}

That possibility of reviving an evil dead rogue "nine times" was Mary's reason for her Creature to disappear into the snow and ice, to "ascend my funeral pyre triumphantly and exult in the agony of the torturing flames". [F:215] If merely drowned or frozen, he could be revived and be a threat anew.

Letters show Carlisle wished his research objectives to be kept secret. Wilkinson recorded of his research into flight, "His [Carlisle's] own opinion was, that the publication, during his life, would injure his practice as a physician" (Wilkinson 1851: 251). In 1817 Carlisle wrote to Cayley; "I have not ventured to speak to any man about these very probable discoveries which may give new physical powers to the human race. I am myself too dependent on my vocation to hazard the abuse and ridicule which a public avowal of such hopes would inevitably afford to my rivals and enemies...there is not one of them you can trust" (Pritchard 1961: 59).

Despite his 1817 preference for literary anonymity, by 1823 Carlisle was knighted, felt more secure, and commissioned Shee to paint his portrait. Shee began the portrait around the time Godwin advertised a new printing of Frankenstein on 16 August 1823. With hindsight, the Parr letter of 5 August 1823, 
the reprinting of Frankenstein, and the Shee portrait were foundations for an orchestrated publicity campaign, to climax when Carlisle revealed his discovery.

\section{Political and Social Pressures on Carlisle, and hence on Mary, in 1826-1831}

Mary had drawn a veil over Carlisle in 1818 , but by 1831 his increased prominence threatened to penetrate that veil. He had not achieved his research objective, and social pressures were causing concern. Mary became increasingly fearful of him being linked to Victor. An example of Carlisle's prominence was a 1826 suggestion his portrait be hung in a proposed national portrait gallery;

Here should we behold Wellington, Nelson, and Abercrombie; Pitt, Sheridan, Burke, and Fox; Wyatt, Arkwright, Rennie, and Watt; the faithful image of the illustrious living and the illustrious dead. Would that in a gallery like this were placed, side by side, Marlborough and the Hero of Waterloo, Sydenham next to Bailey, and on the same line Reynolds's John Hunter, Lawrence's Abernethy, Shee's Sir Anthony Carlisle; Newton the philosopher, and the friend of philosophy in Phillipps's Sir Joseph Banks. Garrick should occupy a conspicuous space; whilst beauty, talent, and virtue, should personate the three graces of the histrionic art in Siddons, Farren, and O’Neil (The London Literary Gazette 1826: 636).

The selection reveals Carlisle, then Surgeon Extraordinary to the King, as far more eminent than any other in the Godwin circle. While conscious public opinion might not endorse his own research, Carlisle did condemn mesmerism, phrenology, and man-midwifery, thus fuelling the ire of Thomas Wakley on issues he was promoting in The Lancet. In 1826 Wakley ridiculed Carlisle as "Sir Anthony Oyster", therein commencing a 15 year character assassination. Attacks by The Lancet and problems with Carlisle's own research paralleled increasing pressure on anatomists. In early 1828 Baron Hullock shocked anatomists when he ruled surgeons in possession of resurrected corpses were acting illegally. The Anatomy Committee met in 1828 and the year climaxed with the infamous trial of Burke and Hare.

These events were set amid social unrest. In 1828, the Duke of Wellington became Prime Minister. He was conservative, fearing the anarchy of the French Revolution would spread to England. Although Wellington had always opposed Catholic Emancipation he reconsidered his views when he became aware of a possible Irish rebellion. Wellington had great difficulty in persuading George IV to accept Emancipation. When Wellington threatened to resign, the King reluctantly agreed. As Surgeon Extraordinary to the King, Carlisle was close to events and helped convince the King. After the Act was passed, Wellington's windows were smashed and iron shutters then installed.

During the upheaval Carlisle was elected President of the Royal College of Surgeons. He presided over the College, with his aim to try to restore public confidence in the profession. In early 1829, Mary moved to 33 Somerset Street, ten minutes walk from Carlisle's home. Early 1829 also saw the famous libel case when Bransby Cooper sought damages from Wakley over claims of surgical 
incompetence. In late 1829 there was a sensational Old Bailey trial of surgeon, Edwin van Butchell, for malpractice and manslaughter, arising from his insertion of an ivory rod into a patient's rectum. Bizarrely, van Butchell's mother was still displayed as a mummy at the RCS. Open season was confirmed on surgeons in 1829, when Mr Heaviside, a surgeon was committed to Newgate on a charge of murder by Mr Forde, the Magistrate, although he had attended a duel between opponents in his professional capacity.

Debate on body-snatching and the Anatomy Bill continued in 1829-1831. The Bill failed in one attempt to pass the House of Lords on 5 June, 1829 as a result of opposition from the Archbishop of Canterbury and the Lord Chief Justice. A week later, on 13 June 1829, The Lancet accused Carlisle and the RCS of moral complicity in the Edinburgh murders by Burke and Hare; "The members of the Council, morally, are scarcely less guilty than the atrocious Burke, and at a public meeting in the autumn, they may, probably, have an opportunity of learning the opinion of their professional brethren on this subject" (The Lancet 1829: 338).

In 1829 the child-bed death of Princess Charlotte and suicide of her manmidwife were fresh in public memory when Carlisle became embroiled in the man-midwifery debate, as President of The British Ladies' Lying-in Institution, a group seeking to protect the role of midwives against man-midwifery. The risk of Carlisle's enemies identifying him as Victor increased in a public letter linking Carlisle as President and Mary Shelley as author of The Last Man; "Sir, The account of the British Ladies Lying-in Institution caused me immediately to conceive, and had not my phreno-gestation been interrupted professionally, I should have brought forth some days ago. ...I know a lady, Mr Editor, who proposes to increase the world without our sex. The author of the Last Man never dreamt of such a crisis" (Medical Gazette 1829: 256).

On 5 September Wakley added more insult, referring to "that anile philosopher, Sir Tabby [sic] Carlisle". Pressures on Carlisle seemed unbearable, but worse was to come. King George IV died on 26 June 1830. A month later, the French Revolution of July 1830 saw the overthrow of King Charles X who fled to England. Carlisle now feared public unrest could arise from public knowledge of his research into reviving the recently dead. Mob hotheads, or even Wakley, might coin the term "Sir Anthony Frankenstein" and spread rumours that he, as Surgeon Extraordinary to George IV, was attempting a Frankenstein type resurrection of the late King.

As political and social tensions increased, particularly those associated with public abhorrence of body-snatching, Mary feared publicity connecting Carlisle with Victor. Mary voiced political concerns in a letter of 11 November 1830 to Lafayette. Four days later, there were alarming reports from the town of Carlisle; "On Monday se'nnight, his Grace the Duke of Wellington, the saviour of his country, was burnt in effigy at the Market Cross, Carlisle; and on Tuesday se'nnight his Majesty's late Principal Secretary of State, Sir Robert Peel, met a similar fate" (Carpenter 1831: 8). On 18 November 1830 the mob threatened Sir Timothy Shelley with violence in his own home.

The risk of Carlisle being linked with Frankenstein is seen in a cartoon from McLean's Monthly Sheet of Caricatures of 1 March 1832, titled Frankenstein's 
Creating Peers (Figure 9). Prime Minister Grey holds a paper labelled "Royal Assent" over a table of new peers and says, "Now I have this Promethean Fire I fear to use it", while an angry Duke of Wellington peers through a window.

Figure 9. Frankenstein's Creating Peers

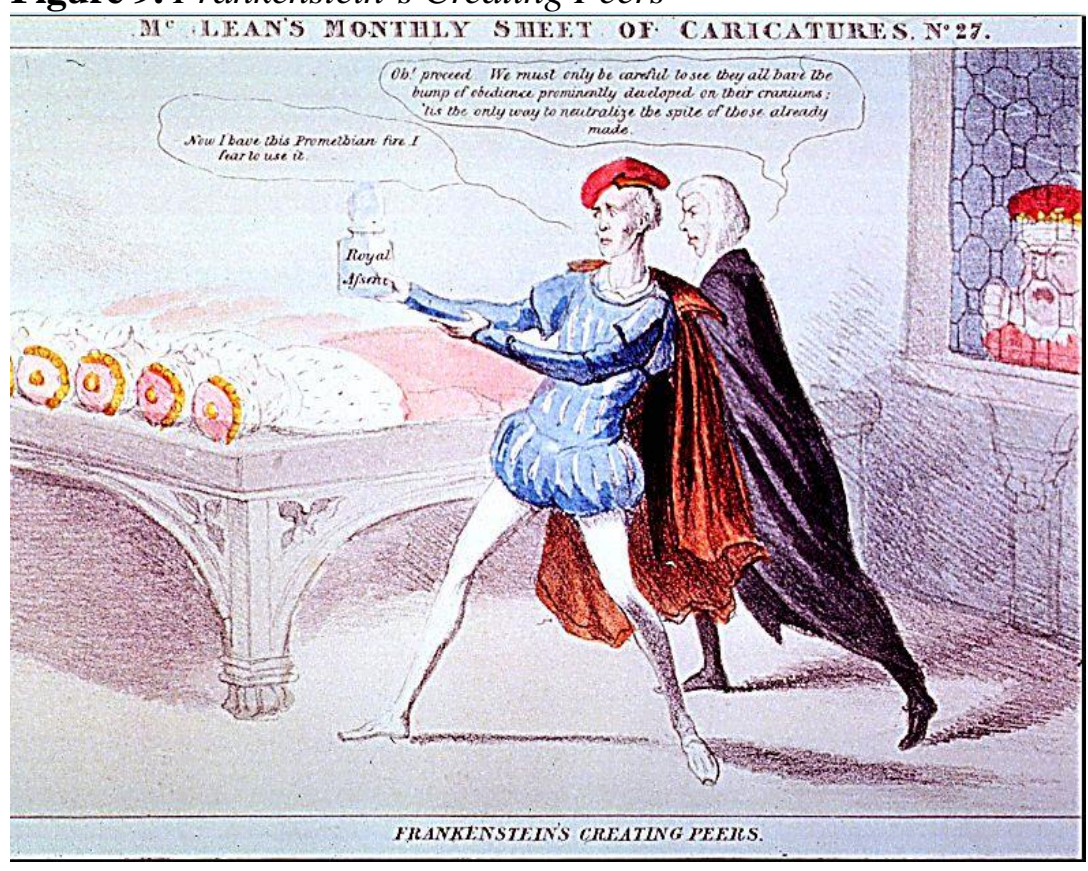

Cartoons in Figaro of 28 April 1832 and 16 March 1833 (Figures 10 and 11) also perceived Victor as evil; "We on a former occasion had to compare Earl Grey to Frankenstein, and he appears again in that character, but in a more objectionable manner [The Coercive Monster], for in the present instance he is fully sensible of the nature of the monster he has produced, and he knows what will be the effect of letting it loose" (Figaro in London 1833: Vol. I, 81, Vol. II, 41).

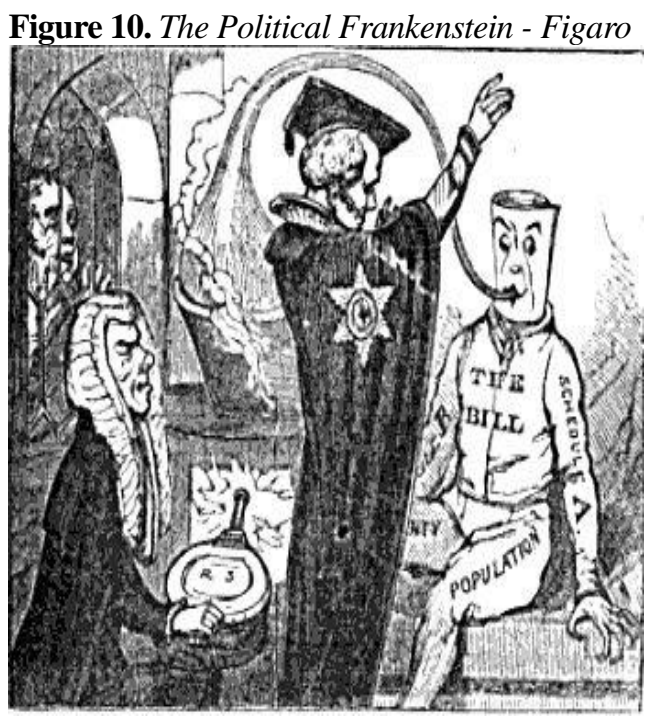

Figure 11. The Coercive Monster-Figaro

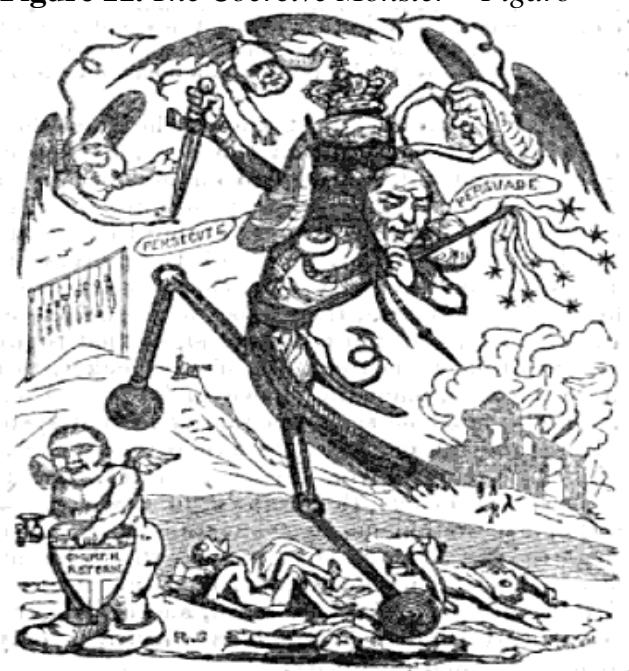




\section{Sanitising Victor}

During 1831 Carlisle and his family remained vulnerable due to the ongoing Anatomy Act debates. With her authorship known and remembering $\mathrm{Mr}$ Platt, a neighbour of Godwin wounded in 1816 by rioters demanding firearms, Mary registered a need to protect the aged Godwin (75), Sir Timothy (78) and Carlisle (63). She expressed her concern about the risk of revolution when writing to Trelawny.

Mary sensed that if Wakley were to coin "Sir Anthony Frankenstein" to add to his previous corrosive epithets, "Sir Anthony Oyster" and "Sir Tabby Carlisle", public reaction might lead to the mob rioting at their homes; with any scandal linking the Monarchy and Carlisle potentially culminating in a British version of the French July Revolution. On 23 June 1831 The Times published Carlisle's concern about a forged letter;

Sir, I feel much obliged by your judicious doubts as to the authenticity of a letter signed "Sir Anthony Carlisle". I have not written that letter, and I am unaware of its tendency; but as it is a forgery, the probability is that it issues from a malignant source. ...Anthony Carlisle.

Table 1. Summary of Editorial Revisions from 1818 to 1831

$\begin{array}{llllll}\text { Page and lines } & 18181831 & \text { Character Key elements } & \text { Impact } \\ \text { p18.21-32 } & 4 & 11 & \text { Captain } & \text { Early life } & * \\ \text { p19.31-20.5 } & 0 & 12 & \text { Walton } & \text { Acknowledges Coleridge's Ancient Mariner } & * \\ \text { p21.25-22 } & 0 & 7 & \text { Walton } & \text { His objective } & * \\ \text { p27.3-28.1 } & 17 & 33 & \text { Victor } & \text { Introducing Victor } & * * \\ \text { p28.18-28 } & 4 & 11 & \text { Victor } & \text { Introducing Victor } & * * \\ \text { p29.1-12 } & 4 & 10 & \text { Victor } & \text { Readying his tale } & * * \\ \text { p29.35-30.3 } & 0 & 6 & \text { Victor } & \text { Readying his tale } & * * \\ \text { p32.24-36.18 } & 58 & 127 & \text { Victor } & \text { Childhood of Elizabeth, mainly romanticising her origin } \\ \text { p36.19-38.4 } & 33 & 55 & \text { Victor } & \text { Childhood and character of Clerval } & * * \\ \text { p38.35-37 } & 2 & 0 & \text { Victor } & \text { Deletes modern chemistry discoveries } & * * \\ \text { p39.8-40.12 } & 29 & 43 & \text { Victor } & \text { Deletes steam and air pump } & * * \\ \text { p40.27-41.22 } & 41 & 34 & \text { Victor } & \text { Deletes electrical machine, kite, chemistry } & * * * \\ \text { p47.9-26 } & 0 & 17 & \text { Victor } & \text { Will pioneer new ways } & * * \\ \text { p55.5-10 } & 4 & 7 & \text { Victor } & \text { Minor rewording } & * \\ \text { p71.25-26 } & 6 & 2 & \text { William } & \text { Softens reference to William's death } & * \\ \text { p77.17-21 } & 10 & 3 & \text { Elizabeth } & \text { Revises the description of Elizabeth } & * \\ \text { p84.32-37 } & 24 & 11 & \text { Justine } & \text { Deletes reference to execution and retribution } & * * \\ \text { p92.8-93.21 } & 33 & 51 & \text { Victor } & \text { Rewording of visit to Alps } & * \\ \text { p149.3-11 } & 6 & 9 & \text { Victor } & \text { Links Clerval to the trip } & * \\ \text { p153.25-31 } & 0 & 6 & \text { Clerval } & \text { Widens Clerval's interests } \\ \text { p176.34-177.11 } & 13 & 16 & \text { Victor } & \text { Deletes responsibility for deaths of William, Justine, and Clerval } & * * \\ \text { p185.29-34 } & 5 & 6 & \text { Victor } & \text { Minor rewording } & * \\ \text { p205.24-27 } & 2 & 3 & \text { Walton } & \text { Minor rewording } & *\end{array}$

It was imperative for Mary to act to diminish the perceived evilness of Victor. Only seven days later, on 30 June 1831, Mary wrote to her publisher, "You made me an offer...concerning the publication of Frankenstein...you would oblige me by communicating about it as soon as you can - You promised me to do so early this week - It is of consequence to both parties that there should be no further delay" (Bennet 1995: 241). 
Mary then deleted, muted, or moderated all implicit references to Carlisle, to make them more generic. Table 1 indicates the magnitude of changes, by comparing line counts for the revisions from 1818 to 1831 , wherein the key changes cluster on pages 36-47 of the 1992 Penguin edition.

The key 1818 statements alluding to Carlisle, together with Mary's 1831 editing, are:

- P 36.19-38.4: Mary had bridged the 1792 to 1818 generation gap with a father/son relationship and in 1831 deleted a reference of concern; "Henry Clerval was the son of...an intimate friend of my father...he wrote a fairy tale [Oakendale], which was the delight and amazement of all his companions".

- P 38.35-37: In 1831 Mary deleted, "should probably have applied myself to the more rational theory of chemistry which has resulted from modern discoveries". This had alluded to Carlisle's discovery of electrolysis, and his silver-nitrate photographic experiments with Thomas Wedgwood.

- P 39.8-40.12: In 1818 Mary mentioned visiting Carlisle; "my utmost wonder was engaged by some experiments on an air pump, which I saw employed by a gentleman whom we were in the habit of visiting". This was replaced by a weak and unconvincing argument as Mary needed to avoid any link to Carlisle's 1804 experiment with an air pump and cadaver's arm, as recalled by Brewster in 1830 (Brewster 1830: 535).

- P 40.27-41.22: A description removed in 1831 is; "He constructed a small electrical machine, and exhibited a few experiments". By 1792 Carlisle was using electricity in experiments and in 1800 he made the first Voltaic battery in England, a "small electrical machine", thence discovering electrolysis.

- P 40.27-41.22: In 1831 Mary added generic wording; "On this occasion a man of great research in natural philosophy was with us". She revised the next sentence to; "All that he said threw greatly into the shade Cornelius Agrippa, Albertus Magnus, and Paracelsus, the lords of my imagination". This was absorbed from Carlisle as implicit in later Select Committee evidence; "For the reading of Hippocrates, Galen, Celsus, and many other of the Roman and Greek medical classics...is perfectly absurd" (Carlisle 1834: 149).

- P 47.9-26: Mary added in 1831; "I will pioneer a new way, explore unknown powers, and unfold to the world the deepest mysteries of creation". More generic in nature, but still similar to Carlisle's 1823 letter to Parr; "The ignorance of the early philosophers on these and several other points".

- P 176.34-177.11: To aid in sanitising Victor, in 1831 Mary deleted; "A bad conscience! Yes, surely I had one. William, Justine, and Clerval, had died through my infernal machinations". 


\section{On the Cusp of Revolution}

Yet more social pressure on Carlisle resulted from his fear of a cholera pandemic; as presciently foreshadowed in Mary's 1826 novel, The Last Man. In July 1831 Carlisle expressed concern in his role as Commissioner of Sewers, but he was ridiculed for his perceptive view cholera was communicated by saliva being contaminated and swallowed.

We perceive that the College of Physicians has decided on the extreme contagious character of cholera, and has recommended quarantine regulations, as strict as if the plague were the disease in question. ...We need scarcely allude to the inane or rather insane speculations of Sir Anthony Carlisle. A more direct puff was never sent forth from Warrens manufactory or Ely Place! It is contemptible in the highest degree (The Medico-chirurgical Review 1831: 286).

Figure 12. A London Board of Health Hunting after Cases like Cholera McLean's Monthly

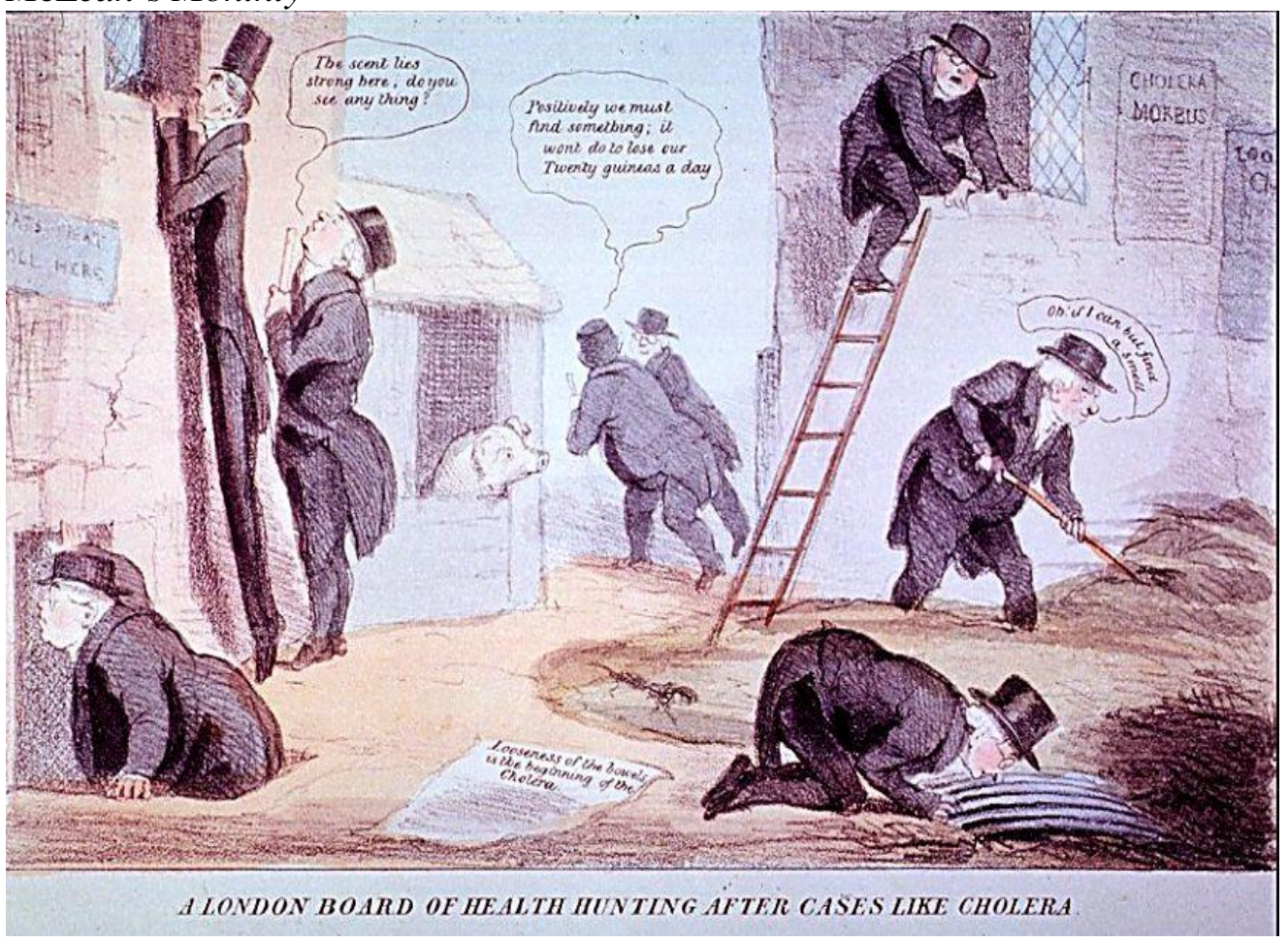

Mary recognised further scorn would harm Carlisle's imperative. On 16 November 1831, when it was realised the pandemic would reach London, Carlisle gave a further lecture on cholera, but his views were ridiculed in The Lancet where Wakley strongly opposed the contagiousness of cholera. The degree of medical confusion is seen in a cartoon from McLean's Monthly of 1832 (Figure 12). One of those depicted, likely Carlisle, says; "The scent lies strong, do you see anything?" It was not until after the 1832 pandemic when 6500 people died that it was conceded; "It is no more than justice to remark that all the statements and predictions of Sir A Carlisle in November last have been completely fulfilled" (Hebert 1832: 41). 
The torrent of events buffeting Carlisle and feeding Mary's fear of revolution fuelled her editorial revision; climaxing on 13 October 1831 when Lord Eldon wrote to Lady Frances of rioting in London;

Our day here yesterday was tremendously alarming... Londonderry has been very seriously hurt. We hear that the mob (but I cannot answer for the truth of it) hanged in effigy the Duke of Wellington and the Duke of Cumberland at Tyburn. The Duke of Newcastle's house, Lord Bristol's, \&c \&c, and all other anti-reforming lords, have been visited and left without glass in their windows. ...I heard last night that the King was frightened by the appearance of people on the outside of St James's (Campbell 1847: 549).

Mary's introduction is dated 15 October 1831, only two days later, but an otherwise puzzling three and a half months after her request for urgency. The 1831 edition was published on 31 October, with the introduction an eleventh-hour inclusion; firmly denying Percy's influence to appease Sir Timothy and insulate him from further mob threats; "I certainly did not owe the suggestion of one incident, nor scarcely one train of feeling, to my husband". [F:10]; and promulgating a mythical dream to deflect attention from Godwin and Carlisle.

Mary's scientific knowledge instead arose as a by-product of Anthony Carlisle's friendship with her father, particularly during discussions in the Godwin home in the impressionable period between her birth and her elopement. Key influences on her were the anatomist's experiments in Oakendale, research by Carlisle into reviving the apparently dead, and his RCS curatorship of the mummies. In 1818 Mary's adolescent immaturity had hinted at Carlisle, but in 1831 that was tempered by her adult acuity and fear of revolution

Methodical, detailed, and logical scrutiny of the 1831 edition of Frankenstein reveals Mary's claim of a dream as being a subterfuge, in simple terms, a lie, invented due to her fear that the truth about her source of inspiration might ignite the prevailing civil unrest; resulting in Britain and its monarchy, together with Sir Timothy Shelley and William Godwin, succumbing to riot and disorder; as had precipitated the 1830 July Revolution in France. Mary floated a mythical legend as her back-story to Frankenstein, but careful analysis suggests it could be described as "the lie that saved the monarchy".

\section{References}

Abernethy J (1814) An enquiry into the probability and rationality of Mr. Hunter's theory of Life. London: Longmans.

Adams J (1818) Memoirs of...John Hunter. London: Callow.

Anon (1899) John Sheldon, Anatomist and Surgeon. London: British Medical Journal.

Bailey JB (1896) The Diary of a Resurrectionist. London: Swan Sonnenschein.

Baillie M (1812) "On the Embalming of Dead Bodies". Transactions Vol. III. London: Nicol.

Bennett BT (1995) Selected Letters of Mary Wollstonecraft Shelley. Baltimore: John Hopkins.

Bewick W (1871) Life and Letters of William Bewick, Vol I. London: Hurst and 
Blackett.

Brewster D (1830) The Edinburgh Encyclopaedia. Edinburgh: Blackwood.

Butler M (1993) The First Frankenstein and Radical Science. London: Times Literary Supplement.

Campbell J (1847) The Lives of the Lord Chancellor Vol. VII. London: Murray.

Carlisle A (1834) Minutes of Evidence. Parliamentary papers, Q 5983. London: Parliament.

Carlisle A (1797/2006) The Horrors of Oakendale Abbey. London: Minerva/Zittaw Press.

Carlisle A (1817) An Essay on the Disorders of Old Age, and on the Means for Prolonging Human Life. London: Longman, Hurst, Rees, Orme, and Brown.

Carlisle A (1797) Elizabeth, Vol. II. London: Minerva.

Carlisle A (1839) The Mechanic's Magazine. London: Robertson.

Carpenter W (1831) Political Letters and Pamphlets. London: Carpenter.

Clarke W (1827) Every Night Book. London: Richardson.

Curran S (2001) The Scientific Grounding of Frankenstein. Retrieved from https://bit.ly/2SoySKc.

Davy J (1814) "An Account of some experiments in animal heat". Philosophical Transactions for 1814. London: Royal Society.

Davy H (1812) Elements of Chemical Philosophy. London: Johnson.

Faujas de St Fond (1799) Travels in England, Scotland, and the Hebrides Vol. I. London: Ridgeway.

Figaro in London Vol. I \& Vol. II (1833) London: Strange.

Fitzpatrick W (1860) Lady Morgan. London: Skeet.

Green Fessenden T (1803) Terrible Tractoration, A poetical petition against galvanising... London: Hurst.

Hebert L (1832) Register of the Arts and Sciences. London: Steill.

Hetherington N (1997) "Creator and Created in Mary Shelley's Frankenstein". KeatsShelley Review 11: 1-39. Windsor: KSMA.

Hindle M (1990) "Vital Matters": Mary Shelley's Frankenstein and Romantic Science. Critical Survey 2(1): 29-35.

Holcroft T (1973) The Adventures of Hugh Trevor. Oxford: Oxford University Press.

Johnstone J (1828) The works of Samuel Parr. London: Longmans.

Lamb C (1905) The Works of Charles and Mary Lamb, edited by EV Lucas. London: Methuen.

LeCussan RJ (2001) "Frankenstein: The Modern Prometheus". Keats-Shelley Review 15: 107-117. Windsor: KSMA.

Leigh S (1824) Leigh's New Picture of London. London: Leigh.

Litten J (1991) The English Way of Death. London: Robert Hale, 1991.

Mellor AK (1988) Mary Shelley, Her Life, Her Fiction, Her Monsters. London: Routledge.

Medical Gazette (1829) London: Longmans.

Monro A (1825) Elements of the anatomy of the human body, Vol I. Edinburgh: Carfrae.

Pritchard JL (1961) Sir George Cayley. London: Parrish.

Shelley M (1992) Frankenstein. London: Penguin.

Shelley M (2008) The Original Frankenstein, edited by CE Robinson. New York: Vintage, 2008.

Shelton DC (2009) "Anthony Carlisle and Mrs Carver." Romantic Textualities 19. Retrieved from https://bit.ly/2EwRS5L.

Smith C (1994) Frankenstein and Natural Magic. In S Bann (Eds.) Frankenstein, 
Creation and Monstrosity. London: Reaktion.

Stephenson Payne LE (2007) With Words and Knives. Aldershot: Ashgate.

Symmons J (1824) The Agamemnon of Aeschylus. London: Taylor and Hessy.

Symmons C, Symmons C (1812) Poems. London: Johnson.

Taylor AS (1858) Medical Jurisprudence. London: Churchill.

The Annual Biography and Obituary (1832) London: Longmans.

The Burlington Magazine (1913) Vol. XXII. London: Burlington.

The London Literary Gazette (1826) London: Proprietors.

The Lancet (1829) London: Wakley.

The Medico-chirurgical Review (1831) London: Johnson.

The New Monthly Magazine (1815) Vol. IV. London: Colburn.,

The New Monthly Magazine (1816) Vol. V. London: Colburn.

Thornton R (1809) "Sketch of the Life of John Sheldon". Monthly Mirror. London: Murray.

Tilloch A (1800) Philosophical Magazine, Vol VI. London: Tilloch.

Wilkinson H (1851) Notes and Queries. London: Bell.

Wrangham F (1804) The Raising of Jairus' Daughter. London: Mawman. 